\title{
6. POTENTIAL FOR HUMAN EXPOSURE
}

\subsection{OVERVIEW}

Bromoform has been identified in at least 140 sites while dibromochloromethane has been identified in at least 174 sites of the 1,662 hazardous waste sites that have been proposed for inclusion on the EPA National Priorities List (NPL) (HazDat 2005). However, the number of sites evaluated for bromoform and dibromochloromethane is not known. The frequency of these sites can be seen in Figures 6-1 and 6-2, respectively. Of these sites, 137 of the 140 bromoform sites are located within the United States, 1 is located in the Virgin Islands (not shown), and 2 are located in the Commonwealth of Puerto Rico (not shown). For dibromochloromethane, 172 of the 174 sites are located within the United States, 1 is located in the Virgin Islands, and 1 is located in the Commonwealth of Puerto Rico.

The principal route of human exposure to dibromochloromethane and bromoform is from the consumption of chlorinated drinking water. These chemicals are thought to form in the water as byproducts from the reaction of chlorine with dissolved organic matter and bromide ions. Dibromochloromethane and bromoform concentrations in water are quite variable, but average levels are usually $<5 \mu \mathrm{g} / \mathrm{L}$.

Most dibromochloromethane and bromoform tend to volatilize from water when exposed to the air. The fate of these chemicals in air has not been investigated, but it is likely they are relatively stable, with halflives of about 1-2 months. Most measurements of the concentration of these chemicals in air indicate that levels are quite low ( $<10 \mathrm{ppt})$.

Neither chemical is strongly adsorbed from water by soil materials, and it is likely that both readily migrate in groundwater. Neither chemical appears to be easily biodegradable under aerobic conditions, but they may readily biodegrade under anaerobic conditions.

\subsection{RELEASES TO THE ENVIRONMENT}

The TRI data should be used with caution because only certain types of facilities are required to report (EPA 1997). This is not an exhaustive list. Manufacturing and processing facilities are required to report 
Figure 6-1. Frequency of NPL Sites with Bromoform Contamination

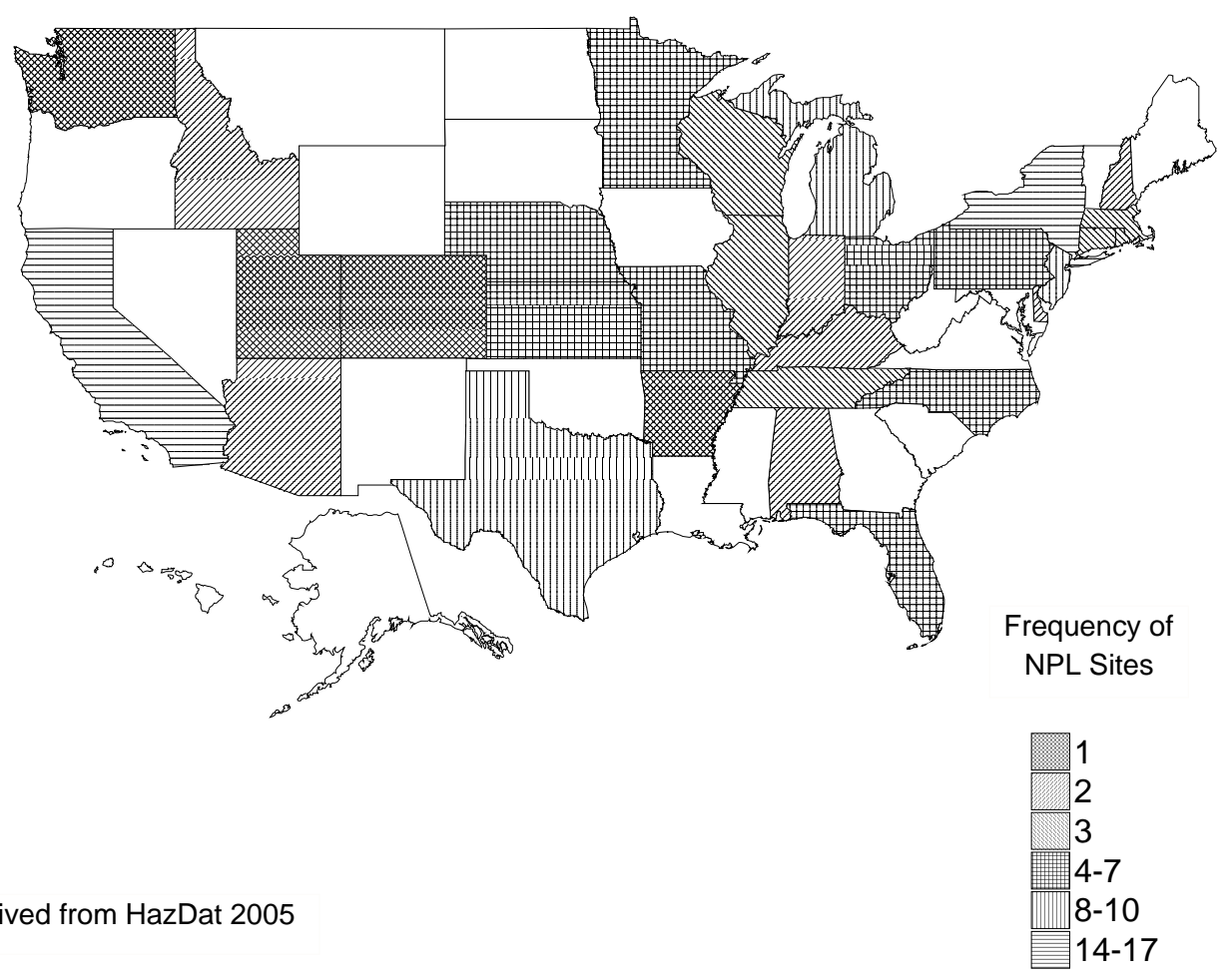


Figure 6-2. Frequency of NPL Sites with Dibromochloromethane Contamination

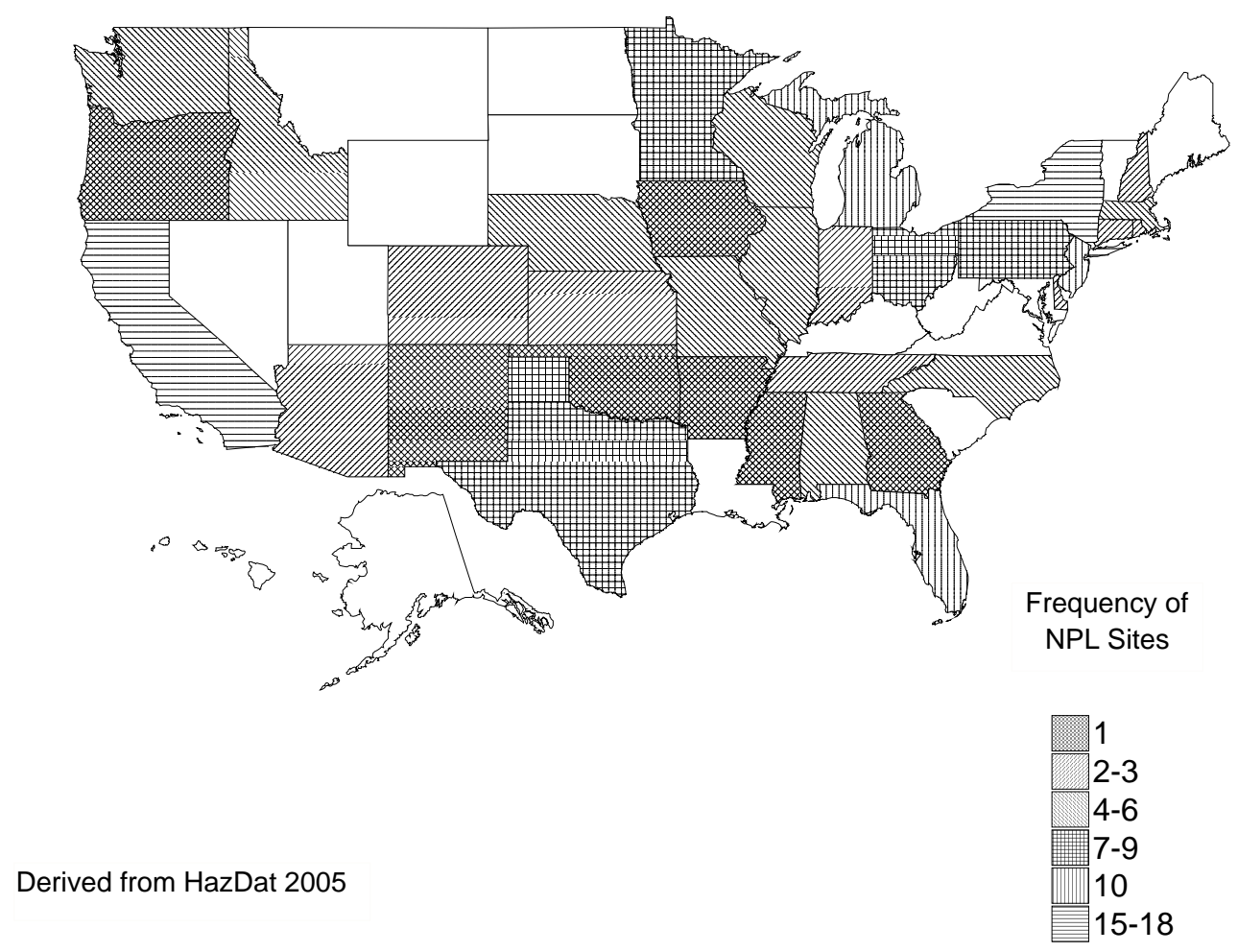


information to the Toxics Release Inventory only if they employ 10 or more full-time employees; if their facility is classified under Standard Industrial Classification (SIC) codes 20-39; and if their facility produces, imports, or processes $\geq 25,000$ pounds of any TRI chemical or otherwise uses $>10,000$ pounds of a TRI chemical in a calendar year (EPA 1997).

Bromoform and dibromochloromethane have been identified in a variety of environmental media (air, surface water, groundwater, soil, and sediment) collected at 140 and 174 of the 1,662 NPL hazardous waste sites, respectively (HazDat 2005).

\subsubsection{Air}

Estimated releases of 12 pounds (0.01 metric tons) of bromoform to the atmosphere from 3 domestic manufacturing and processing facilities in 2002, accounted for about $3 \%$ of the estimated total environmental releases (TRI02 2004). These releases are summarized in Table 6-1.

Bromoform has been identified in air samples collected at 7 of the 140 NPL hazardous waste sites where it was detected in some environmental media (HazDat 2005). Dibromochloromethane has been identified in air samples collected at 1 of the 174 NPL hazardous waste sites where it was detected in some environmental media.

The average concentration of dibromochloromethane in uncontrolled emissions from 40 medical waste incinerators in the United States and Canada was $0.96 \mu \mathrm{g} / \mathrm{kg}$ waste (Walker and Cooper 1992). The average concentration in controlled emissions was $536 \mu \mathrm{g} / \mathrm{kg}$ waste.

Quack and Wallace (2003) estimated that the annual global flux of bromoform of 3-22 Gmol/year with the main source being sea-to-air emissions from macroalgal and planktonic bromoform production. Estimated anthropogenic emission rates for bromoform are $34 \mathrm{Mmol} / \mathrm{year}$ from coastal power plants, $4 \mathrm{Mmol} /$ year from inland nuclear power plants, $280 \mathrm{Mmol} /$ year from coastal fossil fuel plants, $14 \mathrm{Mmol} /$ year from inland fossil fuel plants, $2 \mathrm{Mmol} /$ year from desalination power plants, $12 \mathrm{Mmol} /$ year from water disinfection processes giving a total of $346 \mathrm{Mmol} / \mathrm{year}$ from all anthropogenic sources (Quack and Wallace 2003). Emissions of bromoform from a commercial rice paddy in Houston, Texas were reported to range from 0.012 to $0.032 \mu \mathrm{g} / \mathrm{m}^{2} /$ hour with a median emission rate of $0.021 \mu \mathrm{g} / \mathrm{m}^{2} / \mathrm{hour}$ (Redeker et al. 2003). The mean annual concentrations of bromoform in air extracted from deep firn air 


\section{Table 6-1. Releases to the Environment from Facilities that Produce, Process, or Use Bromoform ${ }^{\mathrm{a}}$}

\begin{tabular}{lrrrrrrrrr}
\hline & & \multicolumn{6}{c}{ Reported amounts released in pounds per year $^{\mathrm{b}}$} \\
\cline { 3 - 10 } State $^{\mathrm{c}}$ & RF $^{\mathrm{d}}$ & Air $^{\mathrm{e}}$ & Water $^{\mathrm{f}}$ & Ul $^{\mathrm{g}}$ & Land $^{\mathrm{h}}$ & Other $^{\mathrm{i}}$ & \multicolumn{4}{c}{ On-site $^{\mathrm{j}}$} & Off-site $^{\mathrm{k}}$ & On- and off-site \\
\hline AR & 1 & 7 & 0 & 0 & 0 & 0 & 7 & 0 & 7 \\
LA & 1 & 0 & 456 & 0 & 0 & 0 & 456 & 0 & 456 \\
NE & 1 & 5 & 0 & 0 & 0 & 0 & 5 & 0 & 5 \\
\hline Total & 3 & 12 & 456 & 0 & 0 & 0 & 468 & 0 & 468 \\
\hline
\end{tabular}

Source: TRI02 2004 (Data are from 2002)

${ }^{a}$ The TRI data should be used with caution since only certain types of facilities are required to report. This is not an exhaustive list. Data are rounded to nearest whole number.

${ }^{\mathrm{b}}$ Data in TRI are maximum amounts released by each facility.

${ }^{\mathrm{C}}$ Post office state abbreviations are used.

${ }^{\mathrm{d}}$ Number of reporting facilities.

${ }^{\mathrm{e}}$ The sum of fugitive and point source releases are included in releases to air by a given facility.

'Surface water discharges, waste water treatment-(metals only), and publicly owned treatment works (POTWs) (metal and metal compounds).

${ }^{\mathrm{g}}$ Class I wells, Class II-V wells, and underground injection.

${ }^{\mathrm{h}}$ Resource Conservation and Recovery Act (RCRA) subtitle C landfills; other on-site landfills, land treatment, surface impoundments, other land disposal, other landfills.

iStorage only, solidification/stabilization (metals only), other off-site management, transfers to waste broker for disposal, unknown

jThe sum of all releases of the chemical to air, land, water, and underground injection wells.

${ }^{\mathrm{k}}$ Total amount of chemical transferred off-site, including to POTWs.

$\mathrm{RF}=$ reporting facilities; $\mathrm{UI}=$ underground injection 
were 1.35 and 0.20 ppt at two Antarctic locations (Sturges et al. 2001). Mean annual concentrations of dibromochloromethane were 0.20 and 0.14 ppt.

No other studies were located regarding the amount of bromoform and dibromochloromethane released into the atmosphere from laboratories, chemical plants, or chemical waste sites. However, since neither compound is produced or used in large quantities (Perwak et al. 1980), atmospheric emissions from these sources are probably small.

\subsubsection{Water}

Estimated releases of 456 pounds ( 0.21 metric tons) of bromoform to surface water and publicly owned treatment works from three domestic manufacturing and processing facilities in 2002, accounted for about 97\% of the estimated total environmental releases (TRI02 2004). These releases are summarized in Table 6-1.

Bromoform has been identified in surface water samples and groundwater samples collected at 14 and 103 of the 140 hazardous waste sites, respectively, where it was detected in some environmental media. Dibromochloromethane has been identified in surface water samples and groundwater samples collected at 15 and 146 of the 174 hazardous waste sites, respectively, where it was detected in some environmental media (HazDat 2005).

The principal anthropogenic source of bromoform and dibromochloromethane in the environment is chlorination of water containing organic materials (Bellar et al. 1974; EPA 1980a; Peters et al. 1994; Rook 1977; Rodriguez et al. 2004; Symons et al. 1975, 1993). It has been estimated that the total amounts of bromoform and dibromochloromethane generated by chlorinating U.S. drinking water in 1978 were 17 and 204 kkg, respectively (Perwak et al. 1980). Bromoform and dibromochloromethane were detected in the distribution systems of three water treatment plants that each use different methods of water chlorination (LeBel et al. 1997). Mean monthly concentrations of dibromochloromethane were $0.2 \mu \mathrm{g} / \mathrm{L}$ in samples from the chlorine-chloramine treatment plant, $0.3 \mu \mathrm{g} / \mathrm{L}$ in samples from the chlorinechlorine treatment plant, and $0.1 \mu \mathrm{g} / \mathrm{L}$ in samples from the ozone-chlorine treatment plant. Mean monthly bromoform concentrations were $<0.1 \mu \mathrm{g} / \mathrm{L}$ in samples from all three plants.

Unlike the chlorination of low-bromide fresh water where chloroform is the trihalomethane produced in the largest amounts, bromoform is the trihalomethane usually produced in the largest amounts during the 
chlorination of sea water or high-bromide fresh water (Khalanski 2003; Richardson et al. 2003). The concentrations of bromoform in the chlorinated cooling water at three European marine power stations on the English Channel were 25.16, 11.4, and $18.23 \mu \mathrm{g} / \mathrm{L}$ (Khalanski 2003). Richardson et al. (2003) measured bromoform concentrations of 23.3, 57, 59, 44, and $55 \mu \mathrm{g} / \mathrm{L}$ in high-bromide water from the Sea of Galilee in Israel after a pre-chlorination step during the months of December, May, September, November, and July, respectively. Concentrations of dibromochloromethanein these samples were reported only for the months of May, September, and July (9.39, 1.9, and $3.7 \mu \mathrm{g} / \mathrm{L}$, respectively).

Ozonation of water containing bromide ion has also been shown to be a source of bromoform in the environment (Glaze et al. 1989; Huang et al. 2003). Bromoform levels were 1.4, 3.7, and $2.1 \mathrm{mg} / \mathrm{L}$ in California State Project Water samples after ozonation at the Los Angeles Aqueduct Filtration Plant in 1987 at ozone doses of 1.0, 2.0, and $4.0 \mathrm{mg} / \mathrm{L}$, respectively (Glaze et al. 1989). Huang et al. (2004) reported that bromoform generation is greater in waters with higher organic matter content.

Release of dibromochloromethane and bromoform into groundwater has been shown to occur as a consequence of the yearly aquifer storage and recovery (ASR) in the Las Vegas Valley. As an example, it is estimated that up to $16.3 \times 10^{6} \mathrm{~m}^{3}$ water was injected into the underlying aquifer during the winter months of 1995-1996, when demand for water by neighboring Las Vegas was low (Thomas et al. 2000). Because the recharge water is chlorinated before injection, byproducts of this disinfection process are introduced into the groundwater at concentrations measured during the 1995-1996 ASR recharge seasons of $18 \mu \mathrm{g} / \mathrm{L}$ for dibromochloromethane and $2.6 \mu \mathrm{g} / \mathrm{L}$ for bromoform in the recharge water. During the water recovery phase beginning in the spring of 1996, initial concentrations of dibromochloromethane and bromoform in water recovered from one recharge well (\#14) in the spring of 1996 were below detection limits $(0.5 \mu \mathrm{g} / \mathrm{L})$ but were much higher, 15 and $2.4 \mu \mathrm{g} / \mathrm{L}$, respectively, in a second well (\#51). Dibromochloromethane and bromoform levels in water recovered from the second well fell during the remaining spring and summer months decreasing to concentrations of 1.5 and $0.6 \mu \mathrm{g} / \mathrm{L}$, respectively, in September of 1996. The differences in the concentrations of dibromochloromethane and bromoform between wells 14 and 51, and the decrease in concentrations observed in water recovered from well 51 during the spring and summer recovery months of 1996, were attributed to both dilution of the recharge water in the aquifer with natural water from the surrounding aquifer basin and biotransformation of the trihalomethanes within the aquifer.

Dibromochloromethane and bromoform may also occur as a consequence of chlorinating industrial waste waters (Perry et al. 1979). Staples et al. (1985) reported that bromoform was detected in 60 of 
1,346 samples of industrial waste effluent, at a median concentration of $<5 \mu \mathrm{g} / \mathrm{L}$, and dibromochloromethane was detected in 84 of 1,298 samples at a median concentration of $<2.4 \mu \mathrm{g} / \mathrm{L}$. These values are not significantly higher than those for typical chlorinated water (see Section 5.4.2), suggesting that industrial discharge may not be a major source of release.

Bromoform and dibromochloromethane were detected in New York City municipal waste water samples taken from 1989 to 1993 (Stubin et al. 1996). Influent concentrations ranged from 7 to $40 \mu \mathrm{g} / \mathrm{L}$ for bromoform with a frequency of detection of $4 \%$ and $9 \mu \mathrm{g} / \mathrm{L}$ for dibromochloromethane with a frequency of detection of 1\%. Effluent concentrations ranged from 3 to $11 \mu \mathrm{g} / \mathrm{L}$ for bromoform with a frequency of detection of $11 \%$ and from 2 to $15 \mu \mathrm{g} / \mathrm{L}$ for dibromochloromethane with a frequency of detection of $8 \%$. Moschandreas et al. (1997) studied samples from 14 New York City waste water pollution control plants to determine the organic compound concentrations in the waste water at each of the plants. Bromoform was detected with concentrations of $0.4-10 \mu \mathrm{g} / \mathrm{L}$ in raw influent samples, 2.0-9.0 $\mu \mathrm{g} / \mathrm{L}$ in primary influent samples, $1.0-10 \mu \mathrm{g} / \mathrm{L}$ in primary effluent samples, $0.3-11 \mu \mathrm{g} / \mathrm{L}$ in aeration tank samples, $0.4-$ $12 \mu \mathrm{g} / \mathrm{L}$ in superficial of return activated sludge samples, and $0.2-12 \mu \mathrm{g} / \mathrm{L}$ in plant effluent samples. Only the plant effluent concentration range $(0.3-5.0 \mu \mathrm{g} / \mathrm{L})$ was reported for dibromochloromethane.

Although most raw water samples collected from different points of the Great Lakes in 1990 contained trihalomethanes at concentrations $<2 \mu \mathrm{g} / \mathrm{L}$, mean concentrations in treated water samples from four of the six locations were above $25 \mu \mathrm{g} / \mathrm{L}$ (Henshaw et al. 1993). The low trihalomethane concentrations of the other two locations are attributed to the use of alternative methods of water treatment such as ammonia addition and potassium permanganate disinfection.

The average concentration of dibromochloromethane in sewage treatment effluents in England and Wales in 1995 was $0.2007 \mu \mathrm{g} / \mathrm{L}$ with a frequency of detection of 30.4\% (Stangroom et al. 1998a). The average concentration of dibromochloromethane in trade effluents in England and Wales in 1995 was $7.91 \mu \mathrm{g} / \mathrm{L}$ with a frequency of detection of $63 \%$.

Mean dibromochloromethane concentrations were determined to be $2 \mathrm{ng} / \mathrm{L}$ in water and sediment samples taken from the anoxic fjord Idefjorden between Norway and Sweden near the city of Halden, Norway (Abrahamsson and Klick 1989). Dibromochloromethane was detected in effluent water from a nearby paper pulp mill. 
Class et al. (1986) observed trace levels of dibromochloromethane and bromoform and other halogenated methanes in sea water (0.1-6 ng/L) and in the air (0.1-20 ppt) at several locations in the Atlantic. Other studies have reported atmospheric bromoform concentration ranges of 1.0-22.7 pptv off the coast of Galway, Ireland, 0.7-8.0 pptv off the coast of northwestern Tasmania, 0.28-2.9 pptv in the West Pacific Islands, $0.32-7.1 \mathrm{pptv}$ in the Asian Seas, and 1.0-37.4 pptv off the Antarctic Peninsula (Carpenter et al. 1999, 2003). Dibromochloromethane was also detected off the coasts of Galway, Ireland and northwestern Tasmania with atmospheric concentrations of 0.13-1.8 and 0.1-1.4 pptv, respectively. The presence of these compounds can be attributed to biosynthesis and release of bromochloromethanes by macroalgae (Carpenter et al. 1999; Class et al. 1986; Gschwend et al. 1985; Marshall et al. 2003; Quack and Wallace 2003). Gschwend et al. (1985) estimated that marine algae could be a major global source of volatile organobromides. More recently, Carpenter and Liss (2000) estimated that macroalgae produce around $70 \%$ of the world's bromoform, which is greater than what was previously estimated due to updated seaweed biomass estimates. However, Class et al. (1986) states that this source accounts for $<1 \%$ of the anthropogenic burden of total organohalogens in the atmosphere.

\subsubsection{Soil}

There were no releases to the ground either through soil or underground injection from three domestic manufacturing and processing facilities in 2002 (TRI02 2004). This information is summarized in Table 6-1.

Bromoform has been identified in soil and sediment samples collected at 26 and 3 of the 140 NPL hazardous waste sites, respectively, where it was detected in some environmental media. Dibromochloromethane has been identified in soil and sediment samples collected at 21 and 4 of the 174 NPL hazardous waste sites, respectively, where it was detected in some environmental media (HazDat 2005).

Soils and other unconsolidated surficial materials may become contaminated with bromoform and dibromochloromethane by chemical spills, the landfilling of halomethane-containing solid wastes, or the discharge of chlorinated water. However, no data were located to suggest that land releases are a significant source of the chemicals in the environment. 


\subsection{ENVIRONMENTAL FATE}

\subsubsection{Transport and Partitioning}

Bromoform and dibromochloromethane are slightly volatile liquids, and tend to exist primarily as vapors in the atmosphere. The vapor pressure of bromoform is $0.007 \mathrm{~atm}$ at $20^{\circ} \mathrm{C}$ (Mabey et al. 1982), and the vapor pressure of dibromochloromethane at $20^{\circ} \mathrm{C}$ is approximately $0.1 \mathrm{~atm}$ (Mabey et al. 1982). The half-time of evaporation from flowing, aerated water (e.g., rivers and streams) has been estimated to range from 1 to 581 hours for bromoform and from 0.7 to 398 hours for dibromochloromethane (Kaczmar et al. 1984; Mackay et al. 1982).

Both dibromochloromethane and bromoform are moderately soluble in water (Callahan et al. 1979; Heikes 1987), and so each may be removed from the air by being dissolved into clouds or raindrops. Estimates of the Henry's law constant $(\mathrm{H})$ (the tendency of a chemical to partition between its vapor phase and water) for bromoform range from 4.3 to $5.6 \times 10^{-4} \mathrm{~atm}-\mathrm{m}^{3} / \mathrm{mole}$, and from 8.7 to $9.9 \times 10^{-4} \mathrm{~atm}-\mathrm{m}^{3} / \mathrm{mole}$ for dibromochloromethane (Mabey et al. 1982; Mackay and Shiu 1981; Munz and Roberts 1987; Nicholson et al. 1984). The magnitude of these values suggest that the two halomethanes will tend to partition to both water and air.

It is not known if either compound can be adsorbed by airborne particulate matter that is subject to atmospheric dispersion, gravitational settling, or wash-out by rain. Particle adsorption is probably not an important transport mechanism because these chemicals occur at such low concentrations in the atmosphere.

Bromoform and dibromochloromethane have a minor tendency to be adsorbed by soils and sediments. Calculated and measured values of $\mathrm{K}_{\mathrm{oc}}$ (the organic carbon/water partition coefficient, an index of the relative mobility of a material in water-soil systems) for bromoform range from 62 to 126 (Hassett et al. 1983; Hutzler et al. 1986; Mabey et al. 1982). These relatively low values imply that bromoform will exhibit only a minor affinity for soil materials and will tend to be highly mobile (Roy and Griffin 1985). This low tendency for adsorption to soil has been confirmed in laboratory studies by Curtis et al. (1986) and in field studies by Roberts et al. (1986).

A similar $\mathrm{K}_{\mathrm{oc}}$ value of 57 has been estimated for dibromochloromethane, based on its measured water solubility (Heikes 1987). No studies were located on the adsorption of dibromochloromethane by soils or 
soil materials, but it is likely that dibromochloromethane will have properties generally similar to those of bromoform.

Bromoform and dibromochloromethane may be slightly bioconcentrated by aquatic organisms. The octanol/water partition coefficient $\left(\mathrm{K}_{\mathrm{ow}}\right)$ (an index of the partitioning of a compound between octanol and water) is approximately 240 for bromoform and 170 for dibromochloromethane (Mabey et al. 1982). The magnitudes of these values suggest that the chemicals will tend to partition to fat tissues of aquatic organisms. No studies were located regarding the bioconcentration factor (BCF) for dibromochloromethane or bromoform, but based on measured BCFs for similar compounds (Kenaga 1980), the BCF of dibromochloromethane and bromoform may be on the order of 2-10. It is not known if these chemicals can be transferred through food chains to higher trophic levels, but this seems unlikely to be of major concern.

The percent removal of dibromochloromethane measured at the outlet of a waste-water-dependent constructed wetland near Phoenix, Arizona was 86.5\% (Keefe et al. 2004). The authors concluded that volatilization was the primary removal mechanism.

\subsubsection{Transformation and Degradation}

\subsubsection{Air}

Based on the behavior of similar compounds, it seems likely that bromoform and dibromochloromethane may be degraded by photooxidative interactions with atmospheric OH radicals. Radding et al. (1977) proposed that the atmospheric half-life of bromoform and dibromochloromethane is approximately 12 months, but this has not been confirmed by direct experimental measurements.

\subsubsection{Water}

Both dibromochloromethane and bromoform are relatively stable in water, with estimated hydrolytic rate constants of $3.2 \times 10^{-11} \mathrm{sec}^{-1}$ and $8 \times 10^{-11} \mathrm{sec}^{-1}$ (Mabey and Mill 1978). These rate constants correspond to hydrolytic half-lives of 686 and 274 years for bromoform and dibromochloromethane, respectively.

No information was located on oxidation or photolysis of these chemicals in water, but it is not expected that either is a significant degradative pathway. 
It has been found that dibromochloromethane and bromoform undergo only limited biodegradation (1025\%) under aerobic conditions, although the rate may increase somewhat after microbial adaptation (Bouwer et al. 1981; Tabak et al. 1981a). Bromoform, at initial concentrations ranging from 132 to $177 \mu \mathrm{g} / \mathrm{L}$, underwent $>99 \%$ reduction in a continuous-flow biofilm column seeded with primary settled sewage with 1.5 hours packed-bed detention time (Cobb and Bouwer 1991). Under anaerobic conditions, dibromochloromethane and bromoform have been found to be readily biodegraded in the presence of methane-producing bacteria (Bouwer and McCarty 1983a; Bouwer et al. 1981), and under denitrifying and sulfate-reducing conditions in batch and column experiments (Bouwer and McCarty 1983b; Bouwer and Wright 1986). There is also some field evidence that trihalomethanes degrade in anaerobic groundwater (Bouwer et al. 1981), with half-lives estimated to be between 21 and 42 days (Bouwer and McCarty 1984). Increased degradation rates were observed for bromoform and dibromochloromethane under conditions similar to those found inside ferrogenic aquifers, especially at higher pH (Kenneke et al. 2003; Pecher et al. 2002). Bouwer and Wright (1986) reported that one degradation product of bromoform was dibromomethane, but there was no additional information on the identity or fate of environmental degradation by-products. Bromoform was not degraded in enriched sea water cultures taken from beds of the giant kelp, M. pyrifera off the coast of California after 40 days (Goodwin et al. 1997).

The concentration of bromoform decreased from $58 \mu \mathrm{g} / \mathrm{L}$ to $<1 \mu \mathrm{g} / \mathrm{L}$ in water stored in an aquifer 7 days after recharge with chlorinated water (Nicholson et al. 2002). The concentration of dibromochloromethane decreased from 46 to $3 \mu \mathrm{g} / \mathrm{L} 28$ days after recharge. The authors stated that the main attenuation processes were most likely adsorption and degradation under methanogenic conditions. McQuarrie and Carlson (2003) suggest that aquifer storage may be a potential method for the removal of disinfection byproducts such as bromoform and dibromochloromethane from treated water.

\subsubsection{Sediment and Soil}

No studies were located regarding the biodegradation of dibromochloromethane or bromoform in soil. It is expected that observations regarding biodegradation rates in aerobic and anaerobic aqueous media (above) will be generally applicable to degradation rates in moist soils. 


\subsubsection{Other Media}

No information was located on the transformation and degradation of bromoform or dibromochloromethane in other media.

\subsection{LEVELS MONITORED OR ESTIMATED IN THE ENVIRONMENT}

Reliable evaluation of the potential for human exposure to bromoform and dibromochloromethane depends in part on the reliability of supporting analytical data from environmental samples and biological specimens. Concentrations of bromoform and dibromochloromethane in unpolluted atmospheres and in pristine surface waters are often so low as to be near the limits of current analytical methods. In reviewing data on bromoform and dibromochloromethane levels monitored or estimated in the environment, it should also be noted that the amount of chemical identified analytically is not necessarily equivalent to the amount that is bioavailable. The analytical methods available for monitoring bromoform and dibromochloromethane in a variety of environmental media are detailed in Chapter 7.

\subsubsection{Air}

Dibromochloromethane and bromoform are usually found in air only at very low concentrations. Brodinsky and Singh (1983) tabulated data on dibromochloromethane and bromoform levels in ambient air from five urban locations across the United States. For dibromochloromethane, 63 of 89 samples were below the detection limit, the mean value was $3.8 \mathrm{ppt}\left(32 \mathrm{ng} / \mathrm{m}^{3}\right)$, and the highest value was $27 \mathrm{ppt}$ $\left(230 \mathrm{ng} / \mathrm{m}^{3}\right)$. For bromoform, 60 of 78 samples were below the detection limit, the mean value was $3.6 \mathrm{ppt}\left(37 \mathrm{ng} / \mathrm{m}^{3}\right)$ and the highest value was $71 \mathrm{ppt}\left(730 \mathrm{ng} / \mathrm{m}^{3}\right)$. Forty-six air samples collected near four chemical plants in Arkansas contained a mean bromoform concentration of $0.9 \mathrm{ppt}\left(9 \mathrm{ng} / \mathrm{m}^{3}\right)$ (Pellizzari 1978). The mean dibromochloromethane concentration was $0.08 \mathrm{ppt}\left(0.8 \mathrm{ng} / \mathrm{m}^{3}\right)$, but 54 of 56 measurements were $<0.05 \mathrm{ppt}\left(0.5 \mathrm{ng} / \mathrm{m}^{3}\right)$.

Fischer et al. (2000) found a nearly constant mixing ratio of bromoform at 0.5 parts per trillion by volume (pptv) in the marine troposphere of the Atlantic across $30^{\circ} \mathrm{W}$ longitude. In the coastal region of South America, bromoform concentrations were $2.4 \mathrm{pptv}$. A high concentration of bromoform (2.0 pptv) was found in an air sample taken near Cape Verde Island. Air mixing ratios for bromoform in samples taken above the waters of the equatorial Pacific during the third joint Soviet-American Gases and Aerosols 
(SAGA 3) experiment ranged from 0.68 to $3.28 \mathrm{pptv}$ using the charcoal or Tenax adsorption method and from 0.5 to 6.7 pptv using the canister collection method (Atlas et al. 1993). Air mixing ratios for dibromochloromethane ranged from 0.09 to 0.49 pptv using the charcoal or Tenax adsorption method. Dibromochloromethane was not measured with the canister collection method. The mean concentration of bromoform in ambient air samples collected in the Arctic Circle was $5.1 \mathrm{ppt}\left(53 \mathrm{ng} / \mathrm{m}^{3}\right)$ (Berg et al. 1984).

During the Urban Air Toxics Monitoring Program, concentrations of bromoform and dibromochloromethane at 13 air monitoring sites located in Vermont, New Jersey, Louisiana, and Texas were $<1$ parts per billion by volume (ppbv) (no detection limit given) (Mohamed et al. 2002). Bromoform was not detected in air samples from three permanent sites in Arizona (Tucson, Payson, and Casa Grande) during the Arizona Hazardous Air Pollutants Monitoring Program, though the detection limit was not specified (Zielinska et al. 1998). Bromoform was detected at a fourth permanent site in Phoenix with a maximum concentration of $0.02 \mathrm{ppbv}$, although the average bromoform concentration at this site was below the detection limit. Bromoform was not detected (detection limit unspecified) in air samples collected from 13 semi-rural to urban locations in Maine, Massachusetts, New Jersey, Pennsylvania, Ohio, Illinois, Louisiana, and California (Pankow et al. 2003). However, dibromochloromethane was detected at Kettering, Ohio at a concentration of $0.007 \mathrm{ppbV}$. This concentration was below the lowest daily standard of $0.057 \mathrm{ppbV}$. Neither bromoform nor dibromochloromethane were detected (detection limit not specified) in air samples from 13 locations in Texas, Louisiana, New Jersey, and Vermont (Mohamed et al. 2002).

The mean, minimum, and maximum concentrations of dibromochloromethane in air samples taken during the Southern California Ozone Study in 1997 were $0.02 \mathrm{ppbv}\left(210 \mathrm{ng} / \mathrm{m}^{3}\right), 0.04 \mathrm{ppbv}\left(420 \mathrm{ng} / \mathrm{m}^{3}\right)$, and $0.01 \mathrm{ppbv}\left(105 \mathrm{ng} / \mathrm{m}^{3}\right)$, respectively at a residential/industrial site in Mexicali, Mexico (Zielinska et al. 2001). Dibromochloromethane was not detected at a residential site in Rosarito, Mexico (no detection limit given). Dibromochloromethane was detected at $24 \mathrm{ppb}\left(0.210 \mathrm{mg} / \mathrm{m}^{3}\right)$ in Finnish industrial air samples medical industry preparing solutions and at $1.6 \mathrm{ppb}\left(0.014 \mu \mathrm{g} / \mathrm{m}^{3}\right)$ in suburban air from Turku, Finland (Kroneld 1989a, 1989b). Dibromochloromethane was not detected in countryside air samples taken from the Islands of Inio at the southwest coast of Finland. Mean concentrations of bromoform detected in air samples collected at two locations in the city of Kaohsiung, Taiwan during the spring of 2002 were 0.25 and $1.00 \mu \mathrm{g} / \mathrm{m}^{3}$ (Lai et al. 2004). 
Bromoform was detected with an occurrence rate of 54\% in indoor air samples taken from 26 houses, although actual concentrations were not given (Kostiainen 1995). Air from 13 houses in Katusushika Ward, Tokyo, Japan were sampled during a survey of indoor pollution by volatile organohalogen compounds in February 1995 (Amagai et al. 1999). Thirty houses were sampled in July 1995. Bromoform was detected in all 13 houses during the February survey. In July, it was detected in 22 out of 30 houses. Dibromochloromethane was detected in all houses during both the February and July surveys. Mean concentrations of dibromochloromethane in February 1995 were $0.016 \mu \mathrm{g} / \mathrm{m}^{3}$ in outdoor air, $0.095 \mu \mathrm{g} / \mathrm{m}^{3}$ in living room air, $0.122 \mu \mathrm{g} / \mathrm{m}^{3}$ in kitchen air, $0.096 \mu \mathrm{g} / \mathrm{m}^{3}$ in bedroom air, and $0.701 \mu \mathrm{g} / \mathrm{m}^{3}$ in bathroom air. Mean concentrations of dibromochloromethane in July 1995 were $0.007 \mathrm{ug} / \mathrm{m}^{3}$ in outdoor air, $0.050 \mu \mathrm{g} / \mathrm{m}^{3}$ in living room air, $0.065 \mu \mathrm{g} / \mathrm{m}^{3}$ in kitchen air, $0.042 \mu \mathrm{g} / \mathrm{m}^{3}$ in bedroom air, and $0.372 \mu \mathrm{g} / \mathrm{m}^{3}$ in bathroom air. Mean concentrations of bromoform in February 1995 were $0.009 \mathrm{ug} / \mathrm{m}^{3}$ in outdoor air, $0.016 \mu \mathrm{g} / \mathrm{m}^{3}$ in living room air, $0.018 \mu \mathrm{g} / \mathrm{m}^{3}$ in kitchen air, $0.015 \mu \mathrm{g} / \mathrm{m}^{3}$ in bedroom air, and $0.091 \mu \mathrm{g} / \mathrm{m}^{3}$ in bathroom air. Mean concentrations of bromoform in July 1995 were $0.010 \mu \mathrm{g} / \mathrm{m}^{3}$ in outdoor air, $0.013 \mu \mathrm{g} / \mathrm{m}^{3}$ in living room air, $0.013 \mu \mathrm{g} / \mathrm{m}^{3}$ in kitchen air, $0.012 \mu \mathrm{g} / \mathrm{m}^{3}$ in bedroom air, and $0.034 \mu \mathrm{g} / \mathrm{m}^{3}$ in bathroom air.

Kerger et al. (2000) evaluated airborne concentrations of common trihalomethane compounds in bathrooms during showering and bathing in three urban homes supplied with chlorinated tap water. Samples were collected prior to, during, and after the water-use event for 16 shower and 7 bath events. The increases in average airborne concentration of dibromochloromethane were $0.5 \mu \mathrm{g} / \mathrm{m}^{3}$ per $\mu \mathrm{g} / \mathrm{L}$ during showers and $0.15 \mu \mathrm{g} / \mathrm{m}^{3}$ per $\mu \mathrm{g} / \mathrm{L}$ during baths.

No studies were located regarding atmospheric concentrations of bromoform or dibromochloromethane in the workplace. Dibromochloromethane was detected in air samples at two hazardous waste sites, but the amounts were not quantified (LaRegina et al. 1986).

\subsubsection{Water}

Dibromochloromethane and bromoform are rarely measurable in nonchlorinated water (Cech et al. 1981; Staples et al. 1985; Varma et al. 1984), but both are very frequently found in chlorinated water. The levels of bromoform and dibromochloromethane in finished (chlorinated) drinking water have been investigated in several studies (see Table 6-2). Except for a few cases, the concentrations of bromoform and dibromochloromethane in drinking water were $<100 \mu \mathrm{g} / \mathrm{L}$, with mean concentrations generally $<10 \mu \mathrm{g} / \mathrm{L}$. 
Table 6-2. Occurrence of Bromoform and Dibromochloromethane in Finished Drinking Water

\begin{tabular}{|c|c|c|c|c|}
\hline \multirow{2}{*}{$\begin{array}{l}\text { Frequency of detection } \\
\text { percent }\end{array}$} & \multicolumn{2}{|c|}{ Concentration $(\mu \mathrm{g} / \mathrm{L})$} & \multirow[b]{2}{*}{ Location } & \multirow[b]{2}{*}{ Reference } \\
\hline & Range & Mean & & \\
\hline \multicolumn{5}{|l|}{ Bromoform } \\
\hline 10 & ND-92 & $\approx 0.4$ & National & Symons et al. 1975 \\
\hline 27 & ND-3.0 & $\approx 0.5$ & 13 Cities & Keith et al. 1976 \\
\hline 34 & NR & 12 & National & Brass et al. 1977 \\
\hline 67 & NR-4.4 & 0.4 & Midwest & ORVWSC 1979 \\
\hline NR & ND-258 & $\approx 7$ & Texas & Glaze and Rawley 1979 \\
\hline 100 & $4-17$ & 9 & Texas & Smith et al. 1980 \\
\hline 26 & NR-110 & NR & National & Westrick et al. 1984 \\
\hline NR & $1-10$ & NR & lowa & Kelley et al. 1985 \\
\hline 8 & ND-1.6 & 0.1 & Michigan & Furlong and D'Itri 1986 \\
\hline NR & NR & $0.8-8$ & California & Wallace et al. 1986b \\
\hline \multicolumn{5}{|l|}{ Dibromochloromethane } \\
\hline 86 & $<0.1-2$ & 0.9 & Ohio & Bellar et al. 1974 \\
\hline NR & $3-32$ & NR & 5 Cities & Coleman et al. 1975 \\
\hline 37 & ND-110 & 2.7 & National & Symons et al. 1975 \\
\hline 85 & ND-15.0 & $\approx 0.4$ & 13 Cities & Keith et al. 1976 \\
\hline 65 & ND-9.0 & 2.9 & lowa & Morris and Johnson 1976 \\
\hline 86 & NR & 14 & National & Brass et al. 1977 \\
\hline 99 & NR-33 & 5.6 & Midwest & ORVWSC 1979 \\
\hline NR & ND-128 & $\approx 20$ & Texas & Glaze and Rawley 1979 \\
\hline 100 & $11-31$ & 20 & Texas & Smith et al. 1980 \\
\hline 42 & NR-63 & NR & National & Westrick et al. 1984 \\
\hline NR & $1-28$ & NR & lowa & Kelley et al. 1985 \\
\hline 75 & ND-40 & 4.1 & Michigan & Furlong and D'Itri 1986 \\
\hline NR & $\mathrm{NR}$ & $1-2$ & New Jersey & Wallace et al. 1986a \\
\hline NR & NR & $8-28$ & California & Wallace et al. 1986b \\
\hline
\end{tabular}

$\mu \mathrm{g}=$ microgram; $\mathrm{L}=$ liter; ND = not detected; NR = not reported 
Bromoform and dibromochloromethane were detected in approximately $90 \%$ of samples from 5,320 wells in 21 states from 1985 to 1995 according to data collected by the United States Geological Survey (USGS) National Water-Quality Assessment Program, although actual concentrations were not given (Lapham et al. 2000). Bromoform and dibromochloromethane were detected in 27 and 39 out of 7,712 California drinking water wells, respectively, during monitoring studies conducted from 1984 to 1990 (Lam et al. 1994). Maximum concentrations were $78 \mu \mathrm{g} / \mathrm{L}$ for bromoform and $30 \mu \mathrm{g} / \mathrm{L}$ for dibromochloromethane. Dibromochloromethane was detected in 5 out of 6 samples from 178 active public supply wells in the Los Angeles physiographic basin, California above the laboratory reporting limit of $0.18 \mu \mathrm{g} / \mathrm{L}$ in August through September 2000 (Shelton et al. 2001). Bromoform was detected in four out of four samples above the laboratory reporting limit of $0.06 \mu \mathrm{g} / \mathrm{L}$. Clark et al. (1994) collected drinking water samples from different points along the North Marin Water District, which serves the greater Novato area in California. Bromoform and dibromochloromethane were detected in the samples with concentrations ranging from 2.4 to $11.4 \mu \mathrm{g} / \mathrm{L}$ and from $<0.1$ to $7.5 \mu \mathrm{g} / \mathrm{L}$, respectively. The concentrations of bromoform and dibromochloromethane were below their detection limits of 0.06 and $0.18 \mu \mathrm{g} / \mathrm{L}$, respectively, in samples collected from 30 groundwater monitoring wells in Wichita, Kansas (USGS 2002). The wells were located in areas of recent residential and commercial development.

The State of California's Water Quality Monitoring Database contains data for public drinking water systems that use either groundwater or surface water sources (Storm 1994). Analysis of these data shows that bromoform was detected in 145 out of 11,765 samples (1.2\%) and dibromochloromethane was detected in 171 out of 11,782 samples (1.5\%). Mean concentrations in samples with detected dibromochloromethane and bromoform were 8.95 and $7.63 \mu \mathrm{g} / \mathrm{L}$, respectively. Occurrence data from approximately 22,000 public water systems (source water: $88 \%$ groundwater and $12 \%$ surface water) from a cross-section of 24 states were selected from the Unregulated Contaminant Information System database (Round 1 monitoring data) (EPA 2001a). Dibromochloromethane and bromoform were detected in these systems with $99^{\text {th }}$ percentile values of 12.7 and $7.3 \mu \mathrm{g} / \mathrm{L}$, respectively. Occurrence data from approximately 27,000 public water systems (source water: $89 \%$ groundwater and $11 \%$ surface water) from a cross-section of 22 states were selected from the Safe Drinking Water Information System database (Round 2 monitoring data). Dibromochloromethane and bromoform were detected in these systems with $99^{\text {th }}$ percentile values of 9.7 and $6.5 \mu \mathrm{g} / \mathrm{L}$, respectively.

It is usually found that halomethanes occur at higher concentrations in drinking water derived from surface sources than those from groundwater supplies because the former tends to contain more dissolved 
organic matter (Bellar et al. 1974; Cech et al. 1981; Glaze and Rawley 1979; Page 1981). The total trihalomethane content of finished water from a given facility can be extremely variable as a function of time (Arguello et al. 1979; Smith et al. 1980), with lower levels of halomethanes usually occurring during the winter.

The mean concentration of dibromochloromethane was $0.74 \mu \mathrm{g} / \mathrm{L}$ in cold season samples from the Elizabethtown, New Jersey water distribution system (Chen and Weisel 1998). Dibromochloromethane levels rose to $1.7 \mu \mathrm{g} / \mathrm{L}$ in warm season samples. Bromoform was not found above the detection limit $(0.10 \mu \mathrm{g} / \mathrm{L})$ in cold season samples from the distribution system, but it was detected in warm season samples with a mean concentration of $0.27 \mu \mathrm{g} / \mathrm{L}$. Summer concentration ranges in treated water immediately prior to distribution in a 1993 national Canadian survey conducted by Health Canada were $<0.1-19.8 \mu \mathrm{g} / \mathrm{L}$ for dibromochloromethane and $<0.1-4.2 \mu \mathrm{g} / \mathrm{L}$ for bromoform (Ritter et al. 2002). Winter concentration ranges were $<0.1-9.0 \mu \mathrm{g} / \mathrm{L}$ for dibromochloromethane and $<0.1-3.3 \mu \mathrm{g} / \mathrm{L}$ for bromoform. Bromoform was detected in the influent, treated, and distribution stages from 47 municipal water treatment plants in Ontario, Canada at concentrations of 0.5, 0-7.0, and 0.2-8.5 $\mu \mathrm{g} / \mathrm{L}$, respectively.

Dibromochloromethane was detected in samples from plant effluents of 35 Finnish waterworks with concentrations ranging from $<0.05$ to $3 \mu \mathrm{g} / \mathrm{L}$ (Nissinen et al. 2002). One exception was a comparatively high concentration of $43 \mu \mathrm{g} / \mathrm{L}$ measured at one of the plants. Bromoform concentrations were $<0.05 \mu \mathrm{g} / \mathrm{L}$ in samples from all plants except for three $(0.48,0.31$, and $27 \mu \mathrm{g} / \mathrm{L})$. Concentrations of bromoform and dibromochloromethane in samples from two Finnish waterworks rose in the spring, changed little over summer and fall, and then dropped during winter. Campillo et al. (2004) detected bromoform in tap water samples collected in Spanish cities at concentrations ranging from 1.8 to $24.7 \mu \mathrm{g} / \mathrm{L}$ (mean=13.5 $\mu \mathrm{g} / \mathrm{L}$ ). The concentrations of dibromochloromethane in these samples ranged from 2.0 to $66.5 \mu \mathrm{g} / \mathrm{L}$ (mean=30 $\mu \mathrm{g} / \mathrm{L}$ ). Mean concentrations of dibromochloromethane and bromoform were $0.5 \mu \mathrm{g} / \mathrm{L}$ and below the detection limit $(0.3 \mu \mathrm{g} / \mathrm{L})$, respectively, in tap water from the city of Cherepovets, Russia (Egorov et al. 2003). Dibromochloromethane was detected in tap water samples collected from the 19 districts of Hong Kong at concentrations ranging from 0.830 to $4.15 \mu \mathrm{g} / \mathrm{L}$ (Lee et al. 2004b). Bromoform was detected (detection limit $0.03 \mu \mathrm{g} / \mathrm{L}$ ) in tap water samples from only 4 of the 19 districts at concentrations ranging from 0.040 to $0.920 \mu \mathrm{g} / \mathrm{L}$.

Bromoform and dibromochloromethane were detected in water samples from seven out of nine household residences in the Lower Rio Grande Valley during the spring of 1993 with concentrations ranging from 1.0 to $14.1 \mu \mathrm{g} / \mathrm{L}$ and from 3.3 to $17.3 \mu \mathrm{g} / \mathrm{L}$, respectively (Berry et al. 1997). These compounds were 
detected in water samples from five out of nine residences in the same region during the summer of 1993 with concentrations ranging from 1.6 to $31.7 \mu \mathrm{g} / \mathrm{L}$ and from 1.8 to $49.9 \mu \mathrm{g} / \mathrm{L}$, respectively.

In order to reduce trihalomethane and related disinfection byproduct concentrations in treated water, communities have begun employing treatment methods that remove disinfection byproduct precursors such as natural organic carbon from the water prior to chlorination (Dey et al. 2001; Peltier et al. 2002; Shetty and Chellam 2003; Weiss et al. 2003; Westerhoff et al. 2004). Some processes employ a coagulation step to aid in filtration or adsorption (Dey et al. 2001; Drikas et al. 2003). Disinfection byproduct removal was studied in the two trains of the Mery-sur-Oise treatment plant, which feeds the northern Parisian Suburbs (Peltier et al. 2002). The newer train uses nanofiltration technology while the older train employs conventional treatment. Trihalomethane concentrations in water treated by the nanofiltration train were $50 \%$ less than trihalomethane concentrations in water treated by the conventional train. Weiss et al. (2002, 2003) observed that levels of total organic carbon and dissolved organic carbon in water from the Ohio, Wabash, and Missouri Rivers were reduced by 35-67\% after riverbank filtration. However, the brominated trihalomethane precursors were not removed as efficiently as the chlorinated trihalomethane precursors ( $<40 \%$ compared to $80 \%$ ). This was attributed to the increase in the bromide to total organic carbon ratio as the water traveled from the rivers to the collection wells.

Trihalomethanes may also form in chlorinated swimming pools (Beech et al. 1980). For fresh water pools, chloroform and dichlorobromomethane were usually the predominant THM species present, with dibromochloromethane and bromoform averaging 3-15 and 1-2 $\mu \mathrm{g} / \mathrm{L}$, respectively. However, in saline pools (which have a higher bromide ion content than fresh water pools), bromoform was the major THM present (average concentration of $650 \mu / \mathrm{L}$ ), with lower concentrations (5-27 $\mu \mathrm{g} / \mathrm{L})$ of dibromochloromethane, bromodichloromethane, and chloroform. Concentrations of bromoform and dibromochloromethane were 1.8-2.9 and 3.5-17 $\mu \mathrm{g} / \mathrm{L}$, respectively, in samples taken from three chlorinated sandy bottom swimming areas in September (Mansour et al. 1999). The concentrations of dibromochloromethane were below $40 \mu \mathrm{g} / \mathrm{L}$ in water samples from eight swimming pools in Nagpur, India (Thacker and Nitnaware 2003). Bromoform was detected in samples from only one of the pools at a concentration below $10 \mu \mathrm{g} / \mathrm{L}$.

Dibromochloromethane and bromoform have also been detected in water near hazardous waste sites, although this is not common. Data from the Contract Laboratory Program (CLP) Statistical Data Base (CLPSD 1988) indicated that bromoform was detected in surface water at 2 of 862 hazardous-waste sites; the median concentration was $7 \mu \mathrm{g} / \mathrm{L}$. Dibromochloromethane was detected in only one sample 
(45 $\mu \mathrm{g} / \mathrm{L})$. Bromoform was detected in groundwater samples collected at four sites; the median concentration was $26 \mu \mathrm{g} / \mathrm{L}$. Based on monitoring data from 479 disposal site groundwater investigations that were conducted across the United States, bromoform was detected in groundwater samples from 10 hazardous waste disposal sites and dibromochloromethane has been detected in groundwater samples from 8 hazardous waste disposal sites (Plumb 1991). Actual concentrations of bromoform and dibromochloromethane were not given.

In a random survey of 954 community water systems, bromoform and dibromochloromethane were detected (minimum reporting limit of $0.2 \mu \mathrm{g} / \mathrm{L}$ ) in 3.4 and 5.5\%, respectively, of source water samples (Delzer and Ivahnenko 2003). Both bromoform and dibromochloromethane were detected more frequently in groundwater sources than surface water sources. Concentrations of bromoform in groundwater ranged from 0.19 to $2.61 \mu \mathrm{g} / \mathrm{L}$ with a median value of $0.26 \mu \mathrm{g} / \mathrm{L}$; in surface water, the concentrations ranged from 0.03 to $0.06 \mu \mathrm{g} / \mathrm{L}$ with a median value of $0.05 \mu \mathrm{g} / \mathrm{L}$. For dibromochloromethane, concentrations in groundwater ranged from 0.02 to $2.43 \mu \mathrm{g} / \mathrm{L}$ with a median value of $0.04 \mu \mathrm{g} / \mathrm{L}$; in surface water, the concentrations ranged from 0.02 to $0.15 \mu \mathrm{g} / \mathrm{L}$ with a median value of $0.03 \mu \mathrm{g} / \mathrm{L}$. In a study of over 21 cities throughout the United States conducted between 1991-1995, dibromochloromethane was detected (minimum reporting limit of $0.2 \mu \mathrm{g} / \mathrm{L}$ ) in $3.4 \%$ of storm water and $0.5 \%$ of shallow groundwater samples (Lopes and Bender 1998). The presence of dibromochloromethane in these samples was attributed to the irrigation of lawns, gardens, and parks with chlorinated water, the draining of swimming pools, and uses of chlorinated water that result in its introduction to storm water catchments.

Dibromochloromethane has been detected at concentrations ranging from 1.1 to $36.3 \mathrm{ng} / \mathrm{L}$ in the Scheldt River estuary, Germany during May 1998; from 0.2 to 22.7 ng/L in Scheldt River estuary, Germany during October 1998; from below the detection limit to $39.0 \mathrm{ng} / \mathrm{L}$ in the Thames River estuary, England during February 1999; from below the detection limit to $7.7 \mathrm{ng} / \mathrm{L}$ in the Loire River estuary, France during September 1998; and from below the detection limit to $9.8 \mathrm{ng} / \mathrm{L}$ in the Rhine River estuary, Germany during November 1997 (Christof et al. 2002). Bromoform and dibromochloromethane were detected in water samples from the Southampton Water estuary at concentrations of 10-2,597 and 102,200 ng/L, respectively (Bianchi et al. 1991).

Bromoform was not found above a detection limit of $0.08 \mu / \mathrm{L}$ in 644 samples from 46 surface water locations, including sea, estuarine, river, and industrial effluent, throughout Portugal (Martinez et al. 2002). Concentrations of bromoform in the Belaya River, Russia were $<0.0001 \mathrm{mg} / \mathrm{L}$ above an industrial zone and $<0.0004 \mathrm{mg} / \mathrm{L}$ below the industrial zone (Safarova et al. 2004). The concentration of 
bromoform in the waste water flowing into this river was measured as $0.0021 \mathrm{mg} / \mathrm{L}$. The concentrations of bromoform and dibromochloromethane in finished water from the city of Hanoi, Vietnam ranged from 1.2 to $8.5 \mu \mathrm{g} / \mathrm{L}$ (average, $6.6 \mu \mathrm{g} / \mathrm{L}$ ) and from 0.3 to $22.3 \mu \mathrm{g} / \mathrm{L}$ (average, $6.3 \mu \mathrm{g} / \mathrm{L}$ ), respectively, in high bromide finished water and from $<0.2$ to $3.7 \mu \mathrm{g} / \mathrm{L}$ (average, $0.5 \mu \mathrm{g} / \mathrm{L}$ ) and from $<0.2$ to $3.8 \mu \mathrm{g} / \mathrm{L}$ (average, $1.8 \mu \mathrm{g} / \mathrm{L}$ ), respectively, in low bromide finished water (Duong et al. 2003). In high bromide finished water that also had high ammonia content, dibromochloromethane was detected at concentrations ranging from $<0.2$ to $3.7 \mu \mathrm{g} / \mathrm{L}$ (average, $0.3 \mu \mathrm{g} / \mathrm{L}$ ), while the concentration of bromoform was $<0.2 \mu \mathrm{g} / \mathrm{L}$. Bromoform and dibromochloromethane have been detected in the Marta River, Italy at concentrations of 2.39-3.35 and 0.04-0.11 $\mu \mathrm{g} / \mathrm{L}$, respectively (Russo et al. 2003). The concentrations of bromoform and dibromochloromethane in the Tiber River, Italy were $0.82-1.82$ and $<16-0.11 \mu \mathrm{g} / \mathrm{L}$, respectively.

\subsubsection{Sediment and Soil}

Staples et al. (1985) reported that bromoform was not detected in any of 353 sediment samples analyzed. No data were available for dibromochloromethane. Data from the Contract Laboratory Program Statistic Data Base (CLPSD 1988) indicated dibromochloromethane and bromoform were detected in soils in only 2 of 862 hazardous waste sites; the median concentrations were $17 \mu \mathrm{g} / \mathrm{kg}$ (bromoform) and $15 \mu \mathrm{g} / \mathrm{kg}$ (dibromochloromethane). Bromoform and dibromochloromethane were detected in sediment samples from the Southampton Water estuary at concentrations ranging from 75 to 62,609 and from 150 to 27,350 ng/kg, respectively (Bianchi et al. 1991). During a monitoring study of volatile halogenated organic compounds in the Klosterhede State Forest District in Jutland, Denmark, bromoform was the only brominated compound detected in soil air samples and only in the upper soil layer with a concentration of $0.25 \mathrm{ng} / \mathrm{L}$ (Laturnus et al. 2000b).

\subsubsection{Other Environmental Media}

The use of chlorinated water in the manufacture of commercially bottled drinks has raised concern over the presence of trihalomethanes in these drinks (McNeal et al. 1995). Levels of dibromochloromethane in bottled water and in carbonated soft drinks ranged from 0.5 to $2 \mathrm{ng} / \mathrm{g}$ in a survey of soft drinks, juices, beers, bottled water, and canned foods purchased from Washington, DC markets in 1991-1992. Bromoform was not found in any of the samples above a detection limit of $0.1 \mathrm{ng} / \mathrm{g}$. Campillo et al. (2004) detected bromoform in pineapple juice, apple juice, and forest fruits juice at concentrations of 4.2, 
3.5, and $2.5 \mu \mathrm{g} / \mathrm{L}$, respectively. Dibromochloromethane was found in pasteurized milk from a suburban area of Turku, Finland (Kroneld and Reunanen 1990).

Neither bromoform nor dibromochloromethane were detected in oyster, clam, or sediment samples from the Ariho and Yoshingaga Rivers in Japan (Gotoh et al. 1992). No detection limit was given. The mean concentrations of bromoform and dibromochloromethane in daily dietary samples collected from housewives in Nogoya and Yokohama, Japan were $0.2-0.6$ and $<0.1-0.2 \mathrm{ng} / \mathrm{g}$, respectively (Toyoda et al. 1990).

\subsection{GENERAL POPULATION AND OCCUPATIONAL EXPOSURE}

Because of the variability of dibromochloromethane and bromoform concentrations in water and air, it is not possible to derive precise estimates of typical human exposure levels. However, based on the typical ranges of dibromochloromethane and bromoform concentrations measured in water and air, it is likely that most individuals will be exposed to average doses of $<1 \mu \mathrm{g} / \mathrm{kg} /$ day (Table 6-3), nearly all of which is from water. Limited data suggest that exposure levels around chemical factories or waste sites are not likely to be much higher, but this can only be evaluated on a site-by-site basis.

The range of dibromochloromethane concentrations in tap water, in blood samples before showering, and in blood samples after showering in Cobb County, Georgia were $<1-4,0.001-0.003$, and 0.003$0.029 \mu \mathrm{g} / \mathrm{L}$, respectively (Miles et al. 2002). Concentrations in tap water, in blood samples before showering, and in blood samples after showering samples from Corpus Christi, Texas were 5-20, 0.0020.031, and 0.011->0.093 $\mu \mathrm{g} / \mathrm{L}$, respectively. Bromoform was detected in the Cobb County, Georgia samples at concentrations of $<1 \mu \mathrm{g} / \mathrm{L}$ in tap water, $0.001-0.0052 \mu \mathrm{g} / \mathrm{L}$ in blood before showering, and 0.0001-0.0059 $\mu \mathrm{g} / \mathrm{L}$ in blood after showering. Concentrations of dibromochloromethane in tap water, in blood samples before showering, and in blood samples after showering from Corpus Christi, Texas ranged from 2-17, 0.001-0.02, and 0.006-0.064 $\mu \mathrm{g} / \mathrm{L}$, respectively. Breath samples of individuals taken within 5 minutes after a shower with high dibromochloromethane and bromoform water concentrations contained dibromochloromethane at a mean concentration of $4.8 \mu \mathrm{g} / \mathrm{m}^{3}$ and bromoform at a mean concentration of $2.3 \mu \mathrm{g} / \mathrm{m}^{3}$ (Weisel 1999). Breath samples taken 5-20 minutes after a shower with high water concentration contained dibromochloromethane at a mean concentration of $2.8 \mu \mathrm{g} / \mathrm{m}^{3}$ and bromoform at a mean concentration of $1.2 \mu \mathrm{g} / \mathrm{m}^{3}$. Breath samples taken $>20$ minutes after a shower with high water concentration contained dibromochloromethane at a mean concentration of $1 \mu \mathrm{g} / \mathrm{m}^{3}$ and bromoform at a mean concentration of $0.6 \mu \mathrm{g} / \mathrm{m}^{3}$. Breath samples from individuals after a shower with 
Table 6-3. Summary of Typical Human Exposure to Bromoform and Dibromochloromethane

\begin{tabular}{lll}
\hline & \multicolumn{2}{c}{ Exposure medium } \\
\cline { 2 - 3 } Parameter & Water & Air \\
\hline Typical concentration in medium & $1-20 \mu \mathrm{g} / \mathrm{L}$ & $0-0.1 \mu \mathrm{g} / \mathrm{m}^{3}$ \\
Assumed intake of medium by $70-\mathrm{kg}$ adult & $2 \mathrm{~L} / \mathrm{day}$ & $20 \mathrm{~m}^{3} / \mathrm{day}$ \\
Assumed absorption fraction & 1.0 & 0.5 \\
Estimated dose to $70-\mathrm{kg}$ adult & $0.03-0.6 \mu \mathrm{g} / \mathrm{kg} / \mathrm{day}$ & $0.0-0.01 \mu \mathrm{g} / \mathrm{kg} / \mathrm{day}$ \\
\hline
\end{tabular}

$\mu \mathrm{g}=$ microgram; $\mathrm{kg}=$ kilogram; $\mathrm{L}=$ liter; $\mathrm{m}^{3}=$ cubic meters 
low water concentration contained dibromochloromethane with a mean concentration of $1 \mu \mathrm{g} / \mathrm{m}^{3}$ at different collection times and bromoform with a mean concentration of $0.6 \mu \mathrm{g} / \mathrm{m}^{3}$ at different collection times.

Blood samples taken from 16 individuals in the Lower Rio Grande Valley during the spring of 1993 had a maximum dibromochloromethane concentration of $0.05 \mu \mathrm{g} / \mathrm{L}$ (38\% frequency of detection) and a maximum bromoform concentration of $0.07 \mu \mathrm{g} / \mathrm{L}$ (19\% frequency of detection) (Buckley et al. 1997). Blood samples taken during the Third National Health and Nutrition Examination Survey, which included over 1,000 individuals, had a maximum dibromochloromethane concentration of $0.024 \mu \mathrm{g} / \mathrm{L}(14.5 \%$ frequency of detection) and a maximum bromoform concentration of $0.034 \mu \mathrm{g} / \mathrm{L}$ ( $9.9 \%$ frequency of detection) (Buckley et al. 1997; Needham et al. 1995).

Dibromochloromethane was found in human kidney and lung tissue at 0.6 and $0.06 \mu \mathrm{g} / \mathrm{kg}$, respectively, in samples taken in the city of Turku, Finland in 1987 (Kroneld 1989a). It was also detected in air samples from that region at a concentration of $0.31 \mathrm{mg} / \mathrm{m}^{3}$. Polkowska et al. (2003) studied the relationship between concentrations of volatile organic halogens in drinking water and the concentrations of these substances in the urine of individuals living in Gdansk-Sopot-Gdynia Tri City area of Poland. Concentrations of dibromochloromethane in drinking water from three locations were 0.015-0.159, 0.912-1.125, and 0.953-0.987 $\mu \mathrm{g} / \mathrm{L}$ with corresponding urine concentrations ranging from not detected to $0.003 \mu \mathrm{g} / \mathrm{L}$, from 0.001 to $0.012 \mu \mathrm{g} / \mathrm{L}$, and from not detected to $0.005 \mu \mathrm{g} / \mathrm{L}$, respectively. Bromoform was only detected in drinking water from two locations at concentrations of $0.018-0.032$ and $0.018-$ $0.045 \mu \mathrm{g} / \mathrm{L}$. It was not detected in any of the urine samples. Detection limits were not provided in this study.

The mean concentrations of bromoform and dibromochloromethane in daily dietary samples collected from housewives in Nogoya and Yokohama, Japan were 0.2-0.6 and $<1-0.2 \mathrm{ng} / \mathrm{g}$, respectively (Toyoda et al. 1990). Based on these concentrations, the mean daily dietary intakes for housewives in these cities were calculated to be $0.5-1.2 \mu \mathrm{g}$ for bromoform and 0-0.5 $\mu \mathrm{g}$ for dibromochloromethane.

Exposure to dibromochloromethane and bromoform may be above average for persons who swim in chlorinated swimming pools. Beech (1980) estimated that the total dose for a 6-year-old boy who swam for 3 hours in a pool containing $500 \mu \mathrm{g} / \mathrm{L}$ of trihalomethanes could be as high as $2.8 \mathrm{mg}(130 \mu \mathrm{g} / \mathrm{kg})$. About $60 \%$ of this dose was attributed to dermal absorption, with about $30 \%$ resulting from inhalation. In fresh water pools, only a small fraction of this would be dibromochloromethane or bromoform, but in a 
salt water pool, a large fraction would be expected to be bromoform (Beech et al. 1980). Aggazzotti et al. (1998) studied the exposure of competitive indoor swimmers to trihalomethanes. The mean concentrations of dibromochloromethane were $0.8 \mu \mathrm{g} / \mathrm{L}$ in the pool water, $5.2 \mu \mathrm{g} / \mathrm{m}^{3}$ in the pool air prior to swimming, and $11.4 \mu \mathrm{g} / \mathrm{m}^{3}$ in pool air during swimming. The mean concentration of bromoform was $0.1 \mu \mathrm{g} / \mathrm{L}$ in the pool water. Bromoform was detected above $0.1 \mu \mathrm{g} / \mathrm{m}^{3}$ in only one air sample. Mean concentrations of dibromochloromethane in the alveolar air sampled from five swimmers were $0.8 \mu \mathrm{g} / \mathrm{m}^{3}$ before swimming and $1.4 \mu \mathrm{g} / \mathrm{m}^{3}$ after 1 hour of swimming. Bromoform was not quantified in any of the alveolar air samples. Calculated dibromochloromethane intakes for the five swimmers were 1.5$1.9 \mu \mathrm{g}$ /hour before swimming and 14-22 $\mu \mathrm{g}$ /hour after 1 hour of swimming.

Individuals who work at indoor pool facilities are expected to be at risk for occupational exposure to trihalomethanes (Fantuzzi et al. 2001). Dibromochloromethane was detected in 24 out of 32 alveolar air samples collected from individuals who work at selected indoor swimming pools in Modena, Italy (Fantuzzi et al. 2001). The mean concentration was $0.5 \mu \mathrm{g} / \mathrm{m}^{3}$. Bromoform was not detected in any of the alveolar air samples above the detection limit of $0.1 \mu \mathrm{g} / \mathrm{m}^{3}$. The authors reported that the concentration of trihalomethanes in the alveolar air of poolside attendants was double that in alveolar air collected from employees working in the engine room and reception area $\left(25.1 \mathrm{vs} .14 .8 \mu \mathrm{g} / \mathrm{m}^{3}\right)$. Mean concentrations of dibromochloromethane measured in this study were $1.9 \mu \mathrm{g} / \mathrm{L}$ in pool water, $3.1 \mu \mathrm{g} / \mathrm{m}^{3}$ in poolside ambient air, $1.5 \mu \mathrm{g} / \mathrm{m}^{3}$ in reception area ambient air, and $1.6 \mu \mathrm{g} / \mathrm{m}^{3}$ in engine room ambient air. The mean concentration of bromoform was $0.4 \mu \mathrm{g} / \mathrm{L}$ in pool water. It was only detected in one ambient air sample (poolside) at a concentration of $0.8 \mu \mathrm{g} / \mathrm{m}^{3}$.

\subsection{EXPOSURES OF CHILDREN}

This section focuses on exposures from conception to maturity at 18 years in humans. Differences from adults in susceptibility to hazardous substances are discussed in Section 3.7, Children's Susceptibility.

Children are not small adults. A child's exposure may differ from an adult's exposure in many ways. Children drink more fluids, eat more food, breathe more air per kilogram of body weight, and have a larger skin surface in proportion to their body volume. A child's diet often differs from that of adults. The developing human's source of nutrition changes with age: from placental nourishment to breast milk or formula to the diet of older children who eat more of certain types of foods than adults. A child's behavior and lifestyle also influence exposure. Children crawl on the floor, put things in their mouths, 
sometimes eat inappropriate things (such as dirt or paint chips), and spend more time outdoors. Children also are closer to the ground, and they do not use the judgment of adults to avoid hazards (NRC 1993).

No information was located regarding the exposures of children to bromoform or dibromochloromethane. Exposures of children to bromoform and dibromochloromethane through inhalation are expected to vary depending on the length of time a child spends indoors and the concentrations of these compounds in indoor air. The concentrations of bromoform and dibromochloromethane will depend on the source of household water, exchange rate of indoor and outdoor air, frequency and duration of showers, and emission rates of these compounds from other household sources (e.g., dishwasher, washing machines, etc.). Dermal exposures of children to bromoform and dibromochloromethane are expected to be lower than, or similar to, those found for adults, depending on frequency and duration of bathing or showering. However, the primary routes of exposure to bromoform and dibromochloromethane are expected to be through drinking water or consumption of beverage or food products that contain water that has been disinfected through chlorination. It is expected that a child's exposure to bromoform and dibromochloromethane will depend predominantly on the source and amount of drinking water consumed per day. Exposure of newborns and infants to bromoform and dibromochloromethane, whose diets are supplemented with human breast milk, cow's milk, or infant formulas, is not known, since measurements of these compounds are not available in these media. Swimming is expected to provide an additional source of exposure for children who spend time in chlorinated swimming pools (Beech et al. 1980).

\subsection{POPULATIONS WITH POTENTIALLY HIGH EXPOSURES}

The environmental medium most likely to be contaminated with bromoform and dibromochloromethane is chlorinated water. Therefore, any person who is in frequent contact with such water could have above average exposures. This includes individuals who drink large quantities of water, such as workers in hot climates, or individuals with swimming pools or saunas, where contact could occur by inhalation or by dermal contact. Since bromoform and dibromochloromethane levels in water depend on the organic content of the source water before chlorination, individuals whose water source is high in organics are likely to have finished water with higher-than-average bromoform and dibromochloromethane levels.

Workers in chemical production facilities or laboratories where bromoform and dibromochloromethane is made or used would also have potentially high exposures to the chemicals, most likely by inhalation or dermal exposure. Persons living near hazardous-waste sites may have potentially high exposures to bromoform and dibromochloromethane, but this can only be evaluated on a case-by-case basis. 


\subsection{ADEQUACY OF THE DATABASE}

Section 104(i)(5) of CERCLA, as amended, directs the Administrator of ATSDR (in consultation with the Administrator of EPA and agencies and programs of the Public Health Service) to assess whether adequate information on the health effects of bromoform and dibromochloromethane is available. Where adequate information is not available, ATSDR, in conjunction with the National Toxicology Program (NTP), is required to assure the initiation of a program of research designed to determine the health effects (and techniques for developing methods to determine such health effects) of bromoform and dibromochloromethane.

The following categories of possible data needs have been identified by a joint team of scientists from ATSDR, NTP, and EPA. They are defined as substance-specific informational needs that if met would reduce the uncertainties of human health assessment. This definition should not be interpreted to mean that all data needs discussed in this section must be filled. In the future, the identified data needs will be evaluated and prioritized, and a substance-specific research agenda will be proposed.

\subsubsection{Identification of Data Needs}

Physical and Chemical Properties. The physical and chemical properties of dibromochloromethane and bromoform have been well studied, and reliable values for key parameters are available for use in environmental fate and transport models. On this basis, it does not appear that further studies of the physical-chemical properties of dibromochloromethane and bromoform are essential.

Production, Import/Export, Use, Release, and Disposal. According to the Emergency Planning and Community Right-to-Know Act of 1986, 42 U.S.C. Section 11023, industries are required to submit substance release and off-site transfer information to the EPA. The TRI, which contains this information for 2002, became available in May of 2004. This database is updated yearly and should provide a list of industrial production facilities and emissions.

Available data indicate that neither bromoform nor dibromochloromethane is produced or used in significant quantities in the United States. Nevertheless, a listing of laboratories or industries that use small amounts in research or testing would be valuable in identifying locations where the potential for 
environmental releases or human exposure exists. Also, information on the means of disposal of waste chemicals would be valuable in identifying environmental media likely to be affected at such sites. Federal regulations do restrict disposal of dibromochloromethane and bromoform to land or in industrial effluents.

Environmental Fate. The fate of dibromochloromethane and bromoform in the environment has not been thoroughly studied, although the physical-chemical properties indicate that both are likely to partition to air and water. Volatilization rates have been calculated for flowing rivers and streams, but direct measurements of half-times of volatilization would be useful, both for surface waters and for household water (showers, baths, cooking, etc.). Adsorption of these compounds to soils and sediments has been studied and does not appear to be a significant factor. Consequently, transport in surface or groundwater are likely to be important. Studies to confirm these expectations and provide more precise descriptions of the environmental behavior of these compounds would be valuable in assessing human exposure near specific sources of release.

Degradation of dibromochloromethane and bromoform in air has not been studied, but is expected to occur by reaction with hydroxyl radicals. Studies to measure the atmospheric half-times of these compounds would be valuable in estimating long-term trends in atmospheric levels, but such studies are probably not essential in estimating exposure near specific sources. Neither chemical undergoes chemical degradation in water, but both are subject to microbial breakdown in water (especially anaerobic groundwater) or moist soils. Further data on the rate of microbial degradation of dibromochloromethane and bromoform in water and soil would be valuable, with special attention to how these rates depend on environmental conditions (oxygen level, pH, etc.).

Bioavailability from Environmental Media. Both dibromochloromethane and bromoform are known to be absorbed following oral and inhalation exposure. No data are available regarding dermal absorption, but it seems likely that uptake across the skin may occur. No data were located regarding the relative bioavailability of dibromochloromethane and bromoform in water, soil or air. Because of their physical and chemical properties, it is expected that the bioavailability of dibromochloromethane and bromoform are not significantly reduced by environmental media, but studies to substantiate this presumption would be helpful.

Food Chain Bioaccumulation. There are few data on bioconcentration of dibromochloromethane or bromoform by plants or aquatic organisms, and no data were located on the bioaccumulation of 
bromoform and dibromochloromethane in the food chain. This lack of data may not be a major limitation because the general levels of the chemicals in water and soil appear to be quite low, and based on the $\mathrm{K}_{\mathrm{oc}}$ of these chemicals, there appears to be a low likelihood of food chain buildup.

Exposure Levels in Environmental Media. Reliable monitoring data for the levels of bromoform and dibromochloromethane in contaminated media at hazardous waste sites are needed so that the information obtained on levels of bromoform and dibromochloromethane in the environment can be used in combination with the known body burden of bromoform and dibromochloromethane to assess the potential risk of adverse health effects in populations living in the vicinity of hazardous waste sites.

There are several studies on the atmospheric concentrations of bromoform and dibromochloromethane in urban and rural environments, but many of the samples did not have detectable levels. No data on levels in air near waste sites were located. More research in this area using more sensitive analytical methods would be helpful, although it is anticipated that typical atmospheric levels will usually be low enough that air is not the principal route of exposure. Data are available on dibromochloromethane and bromoform in a number of chlorinated drinking water systems, and these compounds have been detected in surface water and groundwater near a few hazardous waste sites. Further studies on the levels of these compounds in water and soil around waste sites would be valuable in evaluating the risk to human health posed by these contaminants.

Exposure Levels in Humans. There are no data on levels of dibromochloromethane or bromoform in blood, breath or other tissues from humans residing near waste sites. Low levels of bromoform have been detected in blood of humans, presumably as the result of exposure through ingestion of chlorinated drinking water. Levels in expired breath and in adipose tissue appear to be too low to measure reliably for the general population. Direct measurement of typical human intake from water and air (especially indoor air) would be helpful in obtaining more accurate estimates of typical human dose levels. Similar data on inhalation and dermal doses would be useful for bromoform and dibromochloromethane in and around swimming pools (especially indoor pools).

This information is necessary for assessing the need to conduct health studies on these populations.

Exposures of Children. No formal studies of children's inhalation, dermal, or oral exposures to bromoform and dibromochloromethane were located in the literature. Based on the concentrations of bromoform and dibromochloromethane measured in indoor air and in drinking water that has been 
disinfected by chlorination, studies are needed to assess the inhalation, dermal, and oral exposures of children to these and other disinfection by-products. Data on inhalation and dermal doses would be useful for bromoform and dibromochloromethane in and around swimming pools (especially indoor pools).

Child health data needs relating to susceptibility are discussed in Section 3.12.2, Identification of Data Needs: Children's Susceptibility.

Exposure Registries. No exposure registries for bromoform and dibromochloromethane were located. These compounds are not currently one of the compounds for which a sub-registry has been established in the National Exposure Registry. These compounds will be considered in the future when chemical selection is made for sub-registries to be established. The information that is amassed in the National Exposure Registry facilitates the epidemiological research needed to assess adverse health outcomes that may be related to exposure to this substance.

\subsubsection{Ongoing Studies}

The Federal Research in Progress (FEDRIP 2004) database provides additional information obtainable from a few ongoing studies that may fill in some of the data needs identified in Section 6.8.1. These studies are summarized in Table 6-4. 
Table 6-4. Ongoing Studies on the Potential for Human Exposure to Bromoform ${ }^{\mathrm{a}}$

\begin{tabular}{|c|c|c|c|}
\hline Investigator & Affiliation & Research description & Sponsor \\
\hline $\begin{array}{l}\text { Harrington, J; } \\
\text { Simpson WR }\end{array}$ & $\begin{array}{l}\text { Pennsylvania State } \\
\text { University, University } \\
\text { Park, Pennsylvania; } \\
\text { University of Alaska } \\
\text { Fairbanks Campus, } \\
\text { Fairbanks, Alaska }\end{array}$ & $\begin{array}{l}\text { Development and testing of a radiation-transfer } \\
\text { model for snow photochemistry. This will help } \\
\text { quantify the extent of photochemical processing } \\
\text { of trace compounds within snow and will help in } \\
\text { interpreting ice core climate records and } \\
\text { understanding atmospheric chemistry in snow- } \\
\text { covered regions. The study will include } \\
\text { measurements of photolysis rates for } \\
\text { bromoform. }\end{array}$ & $\begin{array}{l}\text { National } \\
\text { Science } \\
\text { Foundation }\end{array}$ \\
\hline Meyer GJ & $\begin{array}{l}\text { Johns Hopkins } \\
\text { University, Baltimore, } \\
\text { Maryland }\end{array}$ & $\begin{array}{l}\text { Development of new reductive and oxidative } \\
\text { dehalogenation chemistries and the elucidation } \\
\text { of their fundamental mechanisms; application of } \\
\text { these new findings to the sensing, remediation, } \\
\text { and determination of the environmental fate of } \\
\text { organohalide pollutants. The study will provide a } \\
\text { pedagogical platform that informs and educates } \\
\text { the next generation of environmental chemists. }\end{array}$ & $\begin{array}{l}\text { National } \\
\text { Science } \\
\text { Foundation }\end{array}$ \\
\hline Saltzman E & $\begin{array}{l}\text { University of } \\
\text { California-Irvine }\end{array}$ & $\begin{array}{l}\text { The degradation of natural halogenated } \\
\text { compounds in coastal seawater will be studied. } \\
\text { Measurements will be used to revise estimates } \\
\text { for the uptake of atmospheric halocarbons by the } \\
\text { oceans, the extent to which the oceans can } \\
\text { buffer atmospheric halocarbon conc entrations, } \\
\text { and the production rate for these gases in the } \\
\text { surface oceans. }\end{array}$ & $\begin{array}{l}\text { National } \\
\text { Science } \\
\text { Foundation }\end{array}$ \\
\hline
\end{tabular}

${ }^{\mathrm{a}}$ Source: CRIS 2003; FEDRIP 2003, 2004 